\title{
Foam formation in full-scale biogas plants processing biogenic waste
}

\author{
Lucie Moeller ${ }^{*}$ and Kati Görsch
}

\begin{abstract}
Background: The proportion of biogas in the mix of renewable energies is still remarkably high. The process of anaerobic digestion (AD) provides the basis of biogas production but often leads to excessive foaming. Identifying the reasons for foaming is difficult for biogas plant operators because many factors may play a role. It is therefore difficult for laboratory research to give answers to this specific problem, as the consistency of the digestate itself plays a crucial part in the foam formation process. Hence, careful investigation of foaming in full-scale biogas plants is important in order to identify the main causes and to develop strategies for the prevention of foaming.

Methods: Fifteen operators of biogas plants treating biogenic waste have been reviewed in order to estimate the frequency of foaming events in full-scale biogas plants. Samples from foaming digestates were subsequently analyzed. Seven foaming periods in five biogas plants were investigated closely in order to ascertain the causes of foaming events.

Results: It was noted that $80 \%$ of surveyed biogas plants have had excessive foam formation during the AD process. The foam of two wastewater-treating biogas plants contained filamentous microorganisms. An abrupt temperature increase and the use of grain products and yeasts were identified to be the reason for foaming in four cases. It was, however, not possible to identify the real causes of the foaming event in two cases.

Conclusions: Foam formation is a common phenomenon in waste-processing biogas plants. It is important to identify the reasons for foaming because this knowledge helps biogas plant operators to prevent foam formation in the future.
\end{abstract}

Keywords: Full-scale biogas plants; Biogenic waste; Foam formation; Process disturbances

\section{Background}

Biogas plays now an important role in the mix of renewable energies in Germany. This is reflected in the high number of biogas plants. For 2013, the German Biogas Association estimated that there were a total of 7,850 biogas plants and 3,543 MW of total installed electric output [1]. According to the Renewable Energy Statistic Working Group of the German Federal Ministry for Economic Affairs and Energy, biogas accounted for 18.3\% of the total electricity generated from all renewable energy sources in 2013 [2]. In order to operate the biogas plants effectively, the identification of problems during all stages of biogas production is becoming an important issue.

\footnotetext{
* Correspondence: lucie.moeller@ufz.de

UFZ - Helmholtz Centre for Environmental Research, Centre for Environmental Biotechnology, Permoserstrasse 15, 04318 Leipzig, Germany
}

The anaerobic digestion $(\mathrm{AD})$ of organic matter is the core of the overall biogas production process, the main problems of which are over-acidification [3,4], forming of floating layers [5], and excessive foam formation. While the causes of over-acidification and floating layer formation are relatively well understood, the causes of foam formation have remained unidentified to a large extent in practice. There are very few references in the literature concerning this issue. The majority of these publications deal with foam formation in full-scale digesters in wastewater treatment e.g. [6-11]. Nevertheless, in the course of $\mathrm{AD}$ of sewage sludge, the causes of the foaming events are mostly of another nature than in the course of $\mathrm{AD}$ of either biogenic wastes or renewables. Recently, two research papers have been published dealing with foam formation in manure digesters due to organic overloading $[12,13]$. To our knowledge, there exist only

\section{穴 Springer}

(c) 2015 Moeller and Görsch; licensee Springer. This is an Open Access article distributed under the terms of the Creative Commons Attribution License (http://creativecommons.org/licenses/by/4.0), which permits unrestricted use, distribution, and reproduction in any medium, provided the original work is properly credited. 
two papers dedicated to foam formation in a full-scale biogas plant treating biogenic waste until now [5,14]. Lienen et al. [5] analyzed the formation of floating layer and foam in a full-scale biogas plant treating biogenic waste. The authors demonstrated that both phenomena can be reduced by proper stirring and well-controlled substrate feeding. Kougias et al. [14] described a survey of manure-based full-scale biogas plants in Denmark concerning foaming. The authors reported that foam formation is a widespread problem in Denmark affecting 15 of the 16 biogas plants examined. No similar survey has been carried out for German biogas plants so far.

Excessive foaming can cause substantial costs for biogas plant operators due to the need to add anti-foaming agents, for repairing the broken parts of the system, for the cleaning, and for the additional working hours of the staff caused by an enhanced manpower requirement [8-10]. The follow-up costs of a foam event differ from case to case. Westlund et al. [9] described a ten-week foam event in spring 1996 in the digestion tower of a Swedish waste water treatment plant that produced 2,000 $\mathrm{m}^{3}$ biogas per day. The foam problem has led to a reduction of gas production by $40 \%$. Due to the reduction of electricity production, the additional personnel costs, and the increased oil consumption and polymer use in the dewatering phase, a total damage of $\$ 150,000$ was estimated. Kougias et al. [14] reported a loss of about 20\% to $50 \%$ biogas production during foaming periods in full-scale biogas plants in Denmark. In extreme cases, the foaming has led to a total process failure [14].

Foaming is not only influenced by the physicochemical properties of the substrates and/or of the fermentation material, but also by microbial effects, the process management (such as the feeding and stirring cycle), and the geometry of the digester itself $[6,15]$. The mostly described reason for foaming is the organic overload of the digester $[6,13,14]$. Furthermore, the presence of specific substances such as protein [14], fat, oil, and grease [11] as well as suspended particles [6] was found to contribute to foam formation during the $\mathrm{AD}$. Also, the $\mathrm{AD}$ of some substrates such as sugar beet pulp [16,17], acidic whey in connection with chicken manure [14], and slaughterhouse waste [18] is accompanied by enhanced foam formation. Kougias et al. [14] reported that onefifth of the interviewed biogas plant operators could not identify the real causes of foaming in their digester. The inability to find the foaming causes has 'the consequence' that the measures against foaming in biogas reactors are mostly of empirical nature. The common methods are the decrease of the organic load of the digester, the addition of anti-foaming agents, and the optimization of the stirring period $[14,18]$. Unfortunately, there existed no early warning indicator for the prediction of foam formation until now [11]. The only method for estimating the foaming propensity of substrates is the foaming test described in Moeller et al. [19]. The laboratory research of foaming causes and mitigation strategies has many limits as the down-scaling of biological processes may lead to inaccuracy and several effects, e.g. an influence of the agitation devices, which is not transferable to the full-scale plants.

While Germany is the worldwide leader in biogas production, the examination of foaming in full-scale fermenters has been rare so far. Thus, the aim of this report is to provide an insight into the research on the causes of foaming based on full-scale biogas plants that utilize biogenic waste. The investigation was carried out on two levels. Firstly, biogas plant operators in Saxony, Saxony-Anhalt, and Thuringia have been reviewed. The aim of this exercise was to survey the experience of a significant number of plant operators with excessive foaming in their digestates. In addition, foaming biogas plants were visited and sampled in order to examine the foaming causes as well as the possible impact of foaming on the anaerobic digestion process. The present work provides new aspects for the research of foaming in the course of anaerobic digestion in biogas production by showing the abundance of effects that may play a role in the formation and stabilization of foam. This is the first publication that presents a systemic study of foaming causes and mitigation strategies in German full-scale biogas plants.

\section{Methods}

\section{Survey of biogas plant operators}

As clear information with regard to the issues of foaming in full-scale biogas reactors has been rare in the literature, a survey of operators of biogenic waste-utilizing biogas plants was carried out in order to monitor the circumstances of foaming in practice. The interviews are based on a qualitative research design in which the subjective actor statements were placed in the foreground. The interviews were carried out according to a guideline. The range of topics encompassing the main questions covered questions about the frequency of foaming, the supposed causes, and consequences of foam formation as well as measures that were usually applied against foaming. The biogas plant operators were defined to be interlocutors, as they are responsible for the management of the particular biogas plant and are aware of the problems, decisions, and economic consequences of the process set-ups in the digesters.

Operators of all waste-utilizing biogas plants based on liquid fermentation that are operated in Saxony (6), Saxony-Anhalt (6), and Thuringia (6) were contacted. Fifteen biogas plant operators were willing to share their experiences.

Prior to the interviews, e-mails introducing the survey were sent to the operators. Ten interviews were carried 
out by phone; five biogas plant operators were visited. The names of the plants were coded for data protection reasons in order to ensure a free information flow. During the survey analysis, only the technical content of the interviews was evaluated; the assessment of the nonverbal communication was omitted.

\section{Analyses of foaming causes in full-scale fermenters}

Five foaming full-scale biogas plants were sampled in order to examine the causes of foaming more closely. The operational data of the sampled biogas plants are summarized in Table 1 . Approximately $1 \mathrm{~L}$ of digestate was withdrawn via a tap at the side of the fermenter. In the case of BP B, the foam was sampled using an inspection shaft, whereas in the case of BP C, both the outlet of the recirculation pump and the drain of every digester were employed. BP D over-foamed, and foam was collected by its escape from the fermenter. The samples were withdrawn by the biogas plant operators, cooled immediately, and sent in boxes equipped with thermal packs to the laboratory by courier services within 1 day. The analyses were carried out immediately after their arrival.

The samples were pre-treated in order to guarantee their sufficient homogeneity for the analyses. Because the analyses were refined on an ongoing basis, the type of pre-treatment used is indexed in the tables. The original sample without pre-treatment is marked as ' $\mathrm{O}$ '.
The sample was either passed through a sieve with a mesh size of $0.75 \mathrm{~mm}$ (marked as ' $\mathrm{S}$ ') or homogenized using a commercially available blender (marked as ' $\mathrm{B}$ '). The sieved sample was centrifuged ( $20 \mathrm{~min}$, at 5,300 rpm and $20^{\circ} \mathrm{C}$, Avanti 30 Centrifuge, Beckman, Brea, USA; marked as ' $\mathrm{CE}$ ') and filtered afterwards (pressure filtration device SM 16 249, Sartorius, Göttingen, Germany; nylon membrane filter: pore size $0.45 \mu \mathrm{m}$, Whatman, Germany; marked as 'F'). For the analysis of fatty acids, the sample was extracted according to Bligh and Dyer [20] and Morrison and Smith [21] (marked as 'E'). The calculated values are labeled with 'CA'.

The methods used for the analyses of digestates and their foams are summarized in Table 2. VFA/TIC, $\mathrm{pH}$, and concentrations of $\mathrm{NH}_{4}-\mathrm{N}$ and of volatile fatty acids (VFAs) were determined as quantities which are able to confirm the stability of the biogas process according to Switzenbaum et al. [22], Chen et al. [23], and Eder and Schulz [24]. The well-known foam-triggering substances are proteins [6], polysaccharides [25], and lipids [14] as it was reported for sewage sludge $\mathrm{AD}$ and $\mathrm{AD}$ in the rumen. For this reason, the contents of these substances were analyzed. Furthermore, Miltimore et al. [26] assumed that several elements such as calcium, nickel, and zinc influenced the foam formation and stabilization in ruminant $\mathrm{AD}$. For this reason, the analyses of elements that are soluble with water were carried out in digestates.

Table 1 Operating data of the investigated waste utilizing biogas plants

\begin{tabular}{|c|c|c|c|c|c|c|c|}
\hline $\begin{array}{l}\text { Biogas } \\
\text { plant }\end{array}$ & Substrate & $\begin{array}{l}\text { Organic } \\
\text { loading rate }\end{array}$ & Mode of operation & $\begin{array}{l}\text { Installed electric } \\
\text { capacity }\end{array}$ & $\begin{array}{l}\text { Retention } \\
\text { time }\end{array}$ & $\begin{array}{l}\text { Number of } \\
\text { digesters }\end{array}$ & Agitation \\
\hline $\mathrm{BP} A$ & $\begin{array}{l}50 \text { thousand t/a swine and } \\
\text { cattle manure, } 30 \text { thousand } \\
\text { t/a biogenic industrial wastes } \\
\text { from trade and industries }\end{array}$ & $\begin{array}{l}2 \text { to } 2.5 \mathrm{~kg} \\
\mathrm{VS} /\left(\mathrm{m}^{3} \times \text { day }\right)\end{array}$ & $\begin{array}{l}\text { Mesophilic, two-stage } \\
\text { (with an upstream } \\
\text { hydrolysis stage) }\end{array}$ & $\begin{array}{l}2 \times 469 \mathrm{kWel}_{\mathrm{el}} \\
\left(7.4 \mathrm{mil} . \mathrm{kWh}_{\mathrm{e}} / \mathrm{a}\right)\end{array}$ & 25 days & $\begin{array}{l}\text { Two hydrolysis } \\
\text { digesters } \\
\text { (520 } \mathrm{m}^{3} \text { each) } \\
2 \times \text { digesters } \\
\text { (2,300 } \mathrm{m}^{3} \text { each) }\end{array}$ & $\begin{array}{l}\text { Continuous } \\
\text { stirring with } \\
\text { two paddles }\end{array}$ \\
\hline $\mathrm{BP} B$ & $\begin{array}{l}8.320 \text { t/a commercial food } \\
\text { waste, } 3.070 \text { t/a vegetable } \\
\text { materials, } 3.040 \text { t/a grease } \\
\text { separator contents and flotation } \\
\text { tailings, } 1.400 \text { t/a pastry wastes, } \\
170 \text { t/a miscellaneous (dairy } \\
\text { wastewater, potato wastes, } \\
\text { old bread grain sieving wastes) }\end{array}$ & $\begin{array}{l}\left.2.8 \mathrm{~kg}^{3} \times \text { day }\right) \\
\mathrm{VS} /\left(\mathrm{m}^{3} \times \text { da }\right.\end{array}$ & Mesophilic, one-stage & $860 \mathrm{~kW}_{\mathrm{el}}$ & 29 days & $\begin{array}{l}\text { Two digesters } \\
\left(1,000 \mathrm{~m}^{3} \text { each }\right)\end{array}$ & $\begin{array}{l}\text { Recirculation } \\
\text { and pneumatic }\end{array}$ \\
\hline $\mathrm{BP} C$ & $\begin{array}{l}\text { Sewage sludge, approximately } \\
480 \text { to } 640 \text { t grease separator } \\
\text { contents in December } 2009 \\
\text { to March } 2010\end{array}$ & $\begin{array}{l}2.5 \text { to } 3 \mathrm{~kg} \\
\mathrm{VS} /\left(\mathrm{m}^{3} \times \text { day }\right)\end{array}$ & $\begin{array}{l}\text { Mesophilic, } \\
\text { one-stage }\end{array}$ & No information & 20 days & $\begin{array}{l}\text { Four digesters } \\
\left(8,000 \mathrm{~m}^{3} \text { each }\right)\end{array}$ & Recirculation \\
\hline BP D & $\begin{array}{l}36.500 \text { t/a wastes and sludge } \\
\text { from potato processing }\end{array}$ & $\begin{array}{l}\left.2.8 \mathrm{~kg}^{3} \times \text { day }\right) \\
\mathrm{VS} /\left(\mathrm{m}^{3} \times \text { da }\right.\end{array}$ & $\begin{array}{l}\text { Thermophilic, } \\
\text { one-stage }\end{array}$ & $\begin{array}{l}400 \mathrm{~kW}_{\mathrm{el}} \text { the biogas } \\
\text { is burned and heat } \\
\text { is used for the } \\
\text { preparation of } \\
\text { potato products }\end{array}$ & 36 days & $\begin{array}{l}\text { One digester } \\
\left(3,600 \mathrm{~m}^{3}\right)\end{array}$ & Recirculation \\
\hline BP E & $\begin{array}{l}22.800 \text { t/a grain waste } \\
\text { products, } 1.200 \text { t/a grease } \\
\text { separator contents }\end{array}$ & $\begin{array}{l}\text { No } \\
\text { information }\end{array}$ & $\begin{array}{l}\text { Mesophilic, } \\
\text { two-stage (with } \\
\text { open mash and } \\
\text { hydrolysis stage) }\end{array}$ & No information & $\begin{array}{l}30 \text { to } \\
35 \text { days }\end{array}$ & $\begin{array}{l}\text { One digester } \\
\left(5,000 \mathrm{~m}^{3}\right)\end{array}$ & Hydraulic \\
\hline
\end{tabular}


Table 2 Parameters and analytical methods for the evaluation of the fermentation material

\begin{tabular}{|c|c|c|}
\hline Parameter & Sample pre-treatment & Analytical methods and instruments \\
\hline Total solids (TS) & $\mathrm{O}$ & DIN 12880 \\
\hline Volatile solids (VS) & $\mathrm{O}$ & DIN 12879 \\
\hline $\mathrm{pH}$ value & $\mathrm{CE} / \mathrm{S}$ & Microprocessor pH meter pH 95 (WTW, Germany) \\
\hline VFA/TIC & $\mathrm{CE} / \mathrm{S}$ & Titration method according to Nordmann [27] \\
\hline Ammonium-nitrogen $\left(\mathrm{NH}_{4}-\mathrm{N}\right)$ & $\mathrm{F}$ & $\begin{array}{l}\text { DIN } 38406 \text { E5, Spektroquant }{ }^{\oplus} \text { test kit (measuring range } 0.01 \text { to } 3 \mathrm{mg} / \mathrm{L} \\
\mathrm{NH}_{4}-\mathrm{N} \text {, Merck, Germany), photometric measurement with MultiLab P5 } \\
\text { (WTW, Weilheim, Germany) }\end{array}$ \\
\hline Chloride & $\mathrm{F}$ & $\begin{array}{l}\text { Spektroquant }{ }^{\oplus} \text { test kit (measuring range } 2,5 \text { to } 250 \mathrm{mg} / \mathrm{L} \mathrm{Cl}^{-} \text {, Merck, } \\
\text { Darmstadt, Germany), photometric measurement with SpektralPhotometer } \\
\text { CADAS } 200 \text { (Dr. Lange, Düsseldorf, Germany) }\end{array}$ \\
\hline $\begin{array}{l}\text { Volatile fatty acids } \\
\text { (acetate, propionate, butyrate) }\end{array}$ & $\mathrm{F}$ & $\begin{array}{l}\text { High-performance liquid chromatography (Shimadzu, Japan); detector: } \\
\text { RID-10A; column: VA 300/7.8 Nucleogel lon } 300 \mathrm{OA} \text {; eluent: } 0.01 \mathrm{~N} \mathrm{H}_{2} \mathrm{SO}_{4} \text { [28] }\end{array}$ \\
\hline TOC/IC/TC/TN & $\mathrm{B} / \mathrm{S}$ & TOC-VCSH/CSN with a TN unit (Shimadzu, Japan) \\
\hline Crude protein & CA & $\begin{array}{l}\text { Calculated according to Dumas method [29]: Crude protein }=6.25 \times([T N]- \\
\left.\left[\mathrm{NH}_{4}-\mathrm{N}\right]-\left[\mathrm{NO}_{3}-\mathrm{N}\right]-\left[\mathrm{NO}_{2}-\mathrm{N}\right]\right) \text { (The concentrations of nitrate- and nitrite-nitrogen } \\
\text { were neglected due to their low concentration in the digestates as } \\
\text { measured previously.) }\end{array}$ \\
\hline Water-soluble elements & $\mathrm{F}$ & $\begin{array}{l}\text { Inductively coupled plasma atomic emission spectrometry ICP-AES } \\
\text { (Spectroflame, Spectro Int., Kleve, Germany) }\end{array}$ \\
\hline Pattern of fatty acids & E & $\begin{array}{l}\text { GC (System } 5890 \text { Series II GC, Hewlett-Packard, Wilmington, USA) after extraction } \\
\text { according to Bligh and Dyer [20] and Morrison and Smith [21] }\end{array}$ \\
\hline Surface tension & CE & $\begin{array}{l}\text { Drop volume tensiometer (Lauda TV T-1, Lauda Dr. R. Wobser GmbH and Co. } \\
\text { KG, Lauda-Königshofen, Germany) }\end{array}$ \\
\hline
\end{tabular}

\section{Results and discussion}

\section{Survey of foam formation in full-scale biogas plants}

The results of the survey on operators of full-scale biogas plants are summarized in Table 3. Fifteen out of eighteen biogas plant operators were willing to provide information about foam formation in their digesters. Twelve operators (i.e. $80 \%$ of informants) had experience with foaming in their digesters. Two respondents reported foam formation in the biological desulfurization step. Fifty percent of biogas plant operators regularly observed foaming in biogas digesters (Figure 1a), but $42 \%$ had no more problems with foaming at the time of the survey. Twenty-five percent of the operators could not identify the reason for foaming (Figure $1 \mathrm{~b}$ ), and $46 \%$ recognized specific substrates as being responsible for foaming in their fermenter. Substrates that contained proteins, fat, and grease were indicated as foam-forming agents.

Foam was generally suppressed by changing the process management strategy such as increasing the stirring intensity and adjustment of the substrate loading (Figure 1c). Furthermore, diverse additives such as micronutrient mixtures were used to bring excessive foaming under control. The most frequent foam control measures were the lowering of the organic loading rate (OLR) and the addition of anti-foaming agents.

In general, no information could be given about the economic consequences caused by foaming. Only one plant operator reported that foam damaged the roof construction of the digester during an extreme foaming event. The cost of the damage here was estimated at $€ 500,000$.

The survey showed that foaming is a common problem not only in biogas digesters but also in the process of biological desulfurization of biogas. Similar observations had also been made by Kougias et al. [14] who reported about foam formation in both the substrate storage and pre-digesters. The biogas plant operators mostly combated foam after it had appeared which is in agreement with the data published by Kougias et al. [14]. Only a few preventive methods such as the addition of nutrient mixture were carried out. The most common cause of foaming according to Kougias et al. [14] was the organic overload (44\%) followed by feedstock which was high in protein and fat ( $31 \%$ in total) which contradicts the results of the survey described in this paper. A relatively high number of biogas plant operators cannot recognize the foaming causes in their digester $(19 \%$ in [14], 23\% in this study). For this reason, several extensive analyses of foaming causes in full-scale digesters were carried out (see Analysis of foaming causes in full-scale digesters).

\section{Analysis of foaming causes in full-scale digesters Biogas plant $B P A$}

The biogas plant BP A was sampled every second week during 1 year. The aim of the intensive sampling was to study the differences in the behavior of physicochemical 
Table 3 Results of the survey of operators of biogenic waste-treating biogas plants regarding foam formation in digesters

\begin{tabular}{|c|c|c|c|c|c|c|c|c|}
\hline \multirow[b]{2}{*}{$\begin{array}{l}\text { Biogas } \\
\text { plant }\end{array}$} & \multicolumn{3}{|c|}{ Description of surveyed biogas plants } & \multicolumn{5}{|c|}{ Survey results } \\
\hline & Substrates & Capacity & & $\begin{array}{l}\text { Foam } \\
\text { formation }\end{array}$ & $\begin{array}{l}\text { Frequency } \\
\text { of foam } \\
\text { formation }\end{array}$ & $\begin{array}{l}\text { Suspected } \\
\text { causes of } \\
\text { foaming }\end{array}$ & $\begin{array}{l}\text { Foam control } \\
\text { measures }\end{array}$ & $\begin{array}{l}\text { Application of } \\
\text { anti-foaming } \\
\text { agents }\end{array}$ \\
\hline & Saxony & & & & & & & \\
\hline 1 & $\begin{array}{l}\text { Sewage sludge, separately } \\
\text { collected biowaste and } \\
\text { commercial waste }\end{array}$ & 55,000 t/a & $\begin{array}{l}\text { Two digesters } \\
\text { á } 2,300 \mathrm{~m}^{3}\end{array}$ & Yes & $\begin{array}{l}\text { Once a } \\
\text { year }\end{array}$ & $\begin{array}{l}\text { Surfactants, } \\
\text { animal } \\
\text { protein, etc. }\end{array}$ & $\begin{array}{l}\text { Dilution, lowering } \\
\text { the level in } \\
\text { digester, addition } \\
\text { of lime }\end{array}$ & Yes \\
\hline 2 & $\begin{array}{l}\text { See information to BP E } \\
\text { in Table } 1\end{array}$ & & & Yes & Always & Unknown & Agitation & No \\
\hline 3 & $\begin{array}{l}\text { Cattle manure, poultry } \\
\text { manure, grease } \\
\text { separator contents }\end{array}$ & 28,000 t/a & $\begin{array}{l}\text { Two-stage, } \\
\text { mesophilic }\end{array}$ & Yes & $\begin{array}{l}\text { Only at the } \\
\text { beginning }\end{array}$ & Unknown & NA & NA \\
\hline 4 & $\begin{array}{l}\text { See information to BP D } \\
\text { in Table } 1\end{array}$ & & & Yes & Formerly & $\begin{array}{l}\text { Nutrient } \\
\text { deficiency, } \\
\text { overloading }\end{array}$ & $\begin{array}{l}\text { 'Starvation diet', } \\
\text { adjustment of } \\
\text { the feeding system }\end{array}$ & No \\
\hline 5 & $\begin{array}{l}\text { Poultry manure, green } \\
\text { waste, kitchen waste, } \\
\text { grease separator contents, } \\
\text { old food, paper sludge }\end{array}$ & 40,000 t/a & $\begin{array}{l}\text { Two-stage, } \\
\text { mesophilic }\end{array}$ & NA & & & & \\
\hline \multirow[t]{2}{*}{6} & NA & & & NA & & & & \\
\hline & Saxony-Anhalt & & & & & & & \\
\hline 7 & $\begin{array}{l}\text { Biowaste, food waste } \\
\text { from discounter }\end{array}$ & 50,000 t/a & $\begin{array}{l}\text { Coupled dry } \\
\text { and liquid } \\
\text { production }\end{array}$ & Yes & Once & \multicolumn{3}{|c|}{ No more information available } \\
\hline 8 & Biogenic waste & 30,000 t/a & $\begin{array}{l}\text { Single-stage, } \\
\text { thermophilic }\end{array}$ & No & & & & \\
\hline 9 & $\begin{array}{l}\text { Remains of the bioethanol } \\
\text { production }\end{array}$ & 100,000 t/a & NA & \multicolumn{5}{|c|}{ No (foaming problems only in the desulfurization step) } \\
\hline 10 & $\begin{array}{l}\text { Mash from a distillery, } \\
\text { process wastewater from } \\
\text { a potato peeling plant }\end{array}$ & $2,400 \mathrm{~m}^{3} / \mathrm{a}$ & $\begin{array}{l}\text { Single-stage } \\
\left(1,200 \mathrm{~m}^{3}\right)\end{array}$ & Yes & NA & Tensides & NA & NA \\
\hline 11 & $\begin{array}{l}\text { Poultry waste (litter from } \\
\text { the poultry keeping, } \\
\text { flotation tailings, and } \\
\text { wastewater from the } \\
\text { slaughter), grease } \\
\text { and pizza residues }\end{array}$ & $12.400 \mathrm{t} / \mathrm{a}$ & $\begin{array}{l}\text { Two-stage, } \\
\text { mesophilic }\end{array}$ & Yes & $\begin{array}{l}\text { Twice per } \\
\text { year }\end{array}$ & $\begin{array}{l}\text { Nutrient } \\
\text { deficiency }\end{array}$ & $\begin{array}{l}\text { Addition of a } \\
\text { nutrient mixture }\end{array}$ & Yes \\
\hline 12 & $\begin{array}{l}\text { Green waste, commercial } \\
\text { waste, biowaste }\end{array}$ & $21.000 \mathrm{t} / \mathrm{a}$ & $\begin{array}{l}\text { Single-stage, } \\
\text { mesophilic }\end{array}$ & Yes & Regularly & Unknown & $\begin{array}{l}\text { Dilution of } \\
\text { substrate } \\
\text { with water }\end{array}$ & Yes \\
\hline \multirow[t]{2}{*}{13} & Food, commercial waste & $46.000 \mathrm{t} / \mathrm{a}$ & NA & Yes & Once & Overfeeding & $\begin{array}{l}\text { Reduction of } \\
\text { the substrate loading }\end{array}$ & No \\
\hline & Thuringia & & & & & & & \\
\hline 14 & Leftovers & $72.000 \mathrm{t} / \mathrm{a}$ & $\begin{array}{l}\text { Single-stage, } \\
\text { mesophilic }\end{array}$ & Yes & Sometimes & NA & NA & NA \\
\hline 15 & NA & NA & NA & NA & & & & \\
\hline 16 & $\begin{array}{l}\text { Swine manure, paper } \\
\text { fiber residual materials, } \\
\text { slaughterhouse waste }\end{array}$ & NA & $\begin{array}{l}\text { Single-stage, } \\
\text { mesophilic }\end{array}$ & Yes & Formerly & $\begin{array}{l}\text { Protein-containing } \\
\text { slaughterhouse } \\
\text { waste, cellulosic } \\
\text { wastes from a } \\
\text { paper mill }\end{array}$ & $\begin{array}{l}\text { The operator tried } \\
\text { miscellaneous, } \\
\text { but nothing } \\
\text { helped } \\
\text { considerably }\end{array}$ & NA \\
\hline 17 & $\begin{array}{l}\text { Process wastewater } \\
\text { from paper processing }\end{array}$ & NA & NA & \multicolumn{5}{|c|}{ No (foaming problems only in the desulfurization step) } \\
\hline 18 & $\begin{array}{l}\text { Cattle manure, } \\
\text { biowaste, grease } \\
\text { separator contents }\end{array}$ & 30.000 t/a & $\begin{array}{l}\text { Single stage } \\
\left(2 \times 800 \mathrm{~m}^{3}\right), \\
\text { thermophilic }\end{array}$ & Yes & Regularly & $\begin{array}{l}\text { Grease separator } \\
\text { contents }\end{array}$ & $\begin{array}{l}\text { Reduction of the } \\
\text { substrate loading }\end{array}$ & NA \\
\hline
\end{tabular}




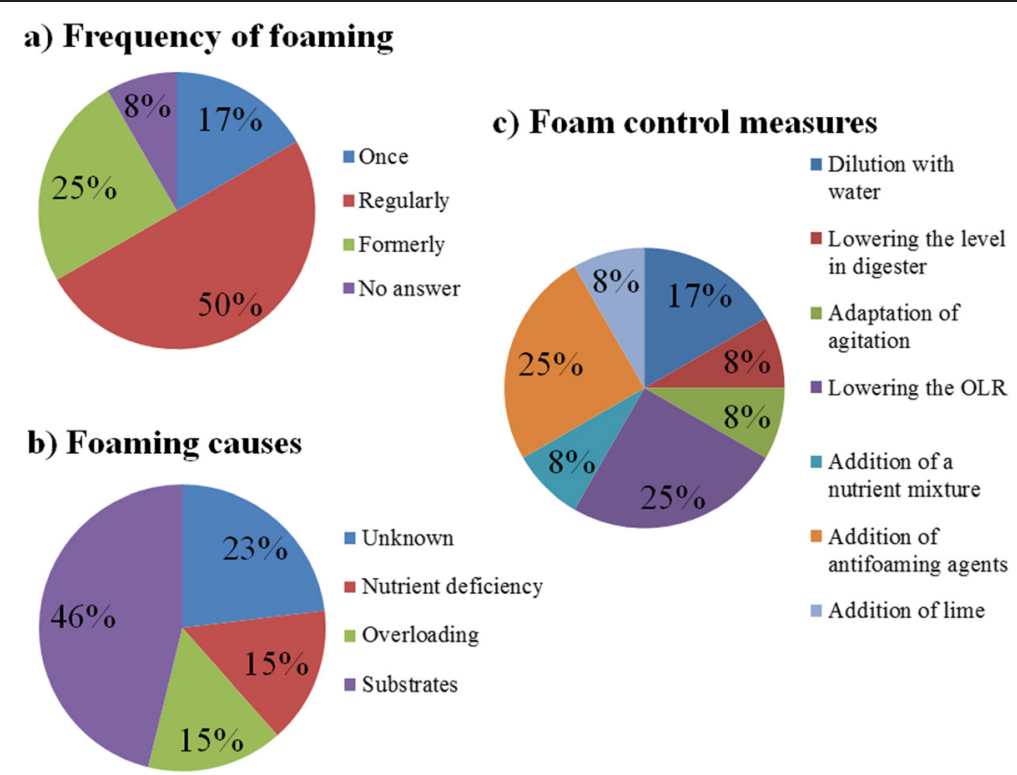

Figure 1 Survey results: frequency of foaming events in digesters (a), most common foaming causes (b) and foam control measures (c) in 15 biogas plants utilizing biogenic waste in Saxony, Saxony-Anhalt, and Thuringia.

parameters in a stable compared to an instable state. The foaming period occurred in the course of the seventh month of the sampling period and lasted 3 days. The biogas plant operator assumed that the reason for foam formation was an abrupt temperature increase from $35^{\circ} \mathrm{C}$ to $38^{\circ} \mathrm{C}$ in both digesters. A part of the digestate was pumped out in order to lower the level in the digesters, so that the foam could be stirred in by fixed- positioned agitators. The foam disappeared after 1 week. No foam sample could be withdrawn from the digesters, so that only digestates were analyzed as described in 'Analyses of foaming causes in full-scale fermenters'.

Data on the chemical analysis of samples which were withdrawn before, during, and after the foaming period are presented in Table 4; the substrate charging during 16 weeks including the foaming period are presented in

Table 4 Comparison of data from the foaming digesters D1 and D2 (biogas plant BP A)

\begin{tabular}{|c|c|c|c|c|c|c|c|}
\hline \multirow{2}{*}{$\begin{array}{l}\text { Time of sampling } \\
\text { Digester }\end{array}$} & \multirow[b]{2}{*}{ Index } & \multicolumn{2}{|c|}{ Two weeks before foaming } & \multicolumn{2}{|c|}{ Day 1 of foaming } & \multicolumn{2}{|c|}{ One week after foaming } \\
\hline & & D1 & D2 & D1 & D2 & D1 & D2 \\
\hline TS [\%] & $\mathrm{O}$ & 3.53 & 1.77 & 4.17 & 3.45 & 3.25 & 2.85 \\
\hline VS $[\%$ TS $]$ & $\mathrm{O}$ & 56.5 & 33.5 & 66.0 & 64.4 & 52.1 & 45.6 \\
\hline $\mathrm{pH}[-]$ & CE & 8.08 & 8.06 & 8.12 & 8.03 & 7.87 & 8.12 \\
\hline VFA/TIC $[-]$ & CE/CA & 0.16 & 0.13 & 0.11 & 0.12 & 0.09 & 0.11 \\
\hline $\mathrm{NH}_{4}-\mathrm{N}[\mathrm{g} / \mathrm{L}]$ & $\mathrm{F}$ & 2.81 & 3.09 & 2.50 & 2.06 & 2.04 & 2.31 \\
\hline Total organic carbon [g/L] & $B$ & 6.52 & 5.44 & 11.1 & 8.68 & 9.10 & 11.26 \\
\hline Total nitrogen $[\mathrm{g} / \mathrm{L}]$ & B & 4.31 & 4.32 & 4.62 & 4.29 & 4.23 & 4.31 \\
\hline Crude protein $[\mathrm{g} / \mathrm{L}]$ & CA & 9.34 & 7.62 & 13.2 & 13.9 & 13.6 & 12.5 \\
\hline Acetic acid [mg/L] & $\mathrm{F}$ & 159 & 182 & 31.4 & 26.5 & 29.5 & 76.7 \\
\hline Propionic acid [mg/L] & $\mathrm{F}$ & $<1$ & $<1$ & $<1$ & $<1$ & $<1$ & $<1$ \\
\hline Butyric acid [mg/L] & $F$ & $<1$ & $<1$ & $<1$ & $<1$ & $<1$ & $<1$ \\
\hline Calcium [mg/L] & $F$ & 12.0 & 48.0 & 41.0 & 58.6 & 43.5 & 21.0 \\
\hline Magnesium [mg/L] & $F$ & 1.41 & 7.23 & 5.05 & 6.06 & 5.91 & 2.31 \\
\hline Phosphorus [mg/L] & $F$ & 300 & 284 & 316 & 305 & 248 & 190 \\
\hline Potassium [mg/L] & $\mathrm{F}$ & 1,148 & 1,188 & 1,130 & 1,159 & 1,096 & 1,190 \\
\hline Sulfur [mg/L] & $\mathrm{F}$ & 301 & 297 & 379 & 332 & 345 & 324 \\
\hline Surface tension [mN/m] & CE & 57.7 & 57.0 & 60.7 & 60.2 & 58.0 & 57.0 \\
\hline
\end{tabular}


Figure 2. The VFA/TIC factor expresses the ratio between the VFA content and total inorganic carbonate buffer, being in fact an indicator for the robustness of the system at high VFA concentrations. Each biogas digester has an own optimum value of VFA/TIC so that one isolated value can give us only little information and, as a consequence, only the comparison of values within one biogas digester makes sense. The VFA/TIC factor was only found to be slightly different in the period before, during, and after foaming and found to show a declining tendency from values of 0.16 (D1) and 0.13 (D2) down to 0.09 (D1) and 0.11 (D2), respectively. The acetic acid concentration decreased in both digesters during the sampling period. Both propionic and butyric acid were below the limit of detection (i.e. $<1 \mathrm{mg} / \mathrm{L}$ ) in all samples. Findings addressing the optimum VFA concentration in the literature have been rare. Hill et al. [30] reported that only concentrations of acetate higher than $13 \mathrm{mM}$ (i.e. approximately $930 \mathrm{mg} / \mathrm{L}$ ) indicate process imbalances. Thus, the acetate content in BP A was uncritical during the whole monitoring periods.

With regard to water-soluble elements, the calcium, phosphorous, and sulfur concentrations had slightly higher values during the foaming period as compared with the rest of the samples from non-foaming periods (Table 4). The magnesium concentrations had an opposite tendency in both digesters, while the potassium content stayed constant during the whole sampling period. The iron, zinc, and nickel concentrations were under the detection limit (i.e. $<1.5 \mathrm{mg} / \mathrm{L} \mathrm{Fe},<2.5 \mathrm{mg} / \mathrm{L} \mathrm{Zn}$, and $<2 \mathrm{mg} / \mathrm{L} \mathrm{Ni}$ ). As described by Miltimore et al. [26], calcium, nickel, and zinc were found to be associated with bloat in the rumen, whereas magnesium was not related to bloat. The authors also demonstrated that contrary to nickel and zinc, calcium was associated with Fraction I protein which is assumed to be the cause of pasture bloat of ruminants [31]. On the other side, Moeller et al. [32] reported about a stabilizing effect of an addition of calcium and magnesium during sugar beet-based foaming in $\mathrm{AD}$. The concentrations of elements as displayed in Table 4 do not allow us to draw conclusions about their influence on foam formation or stabilization as no maximum could be observed during the time of foaming.

Ammonium nitrogen $\left(\mathrm{NH}_{4}-\mathrm{N}\right)$ declined during the sampling period from $3 \mathrm{~g} / \mathrm{L}$ to $2 \mathrm{~g} / \mathrm{L}$. There are many studies concerning the effect of ammonium nitrogen concentration on the AD stability (see [23] for an overview). However, like in the case of VFA, no general optimum could be confirmed by the authors. On the other side, the decrease in the $\mathrm{NH}_{4}-\mathrm{N}$ concentration shows that this parameter could not have a decisive effect on the foamforming procedure.

The crude protein content increased from 9.3 (D1) and 7.6 (D2) to 13.2 (D1) and 13.9 (D2) during foaming as it is illustrated in Figure 3. In the 14 proceeding weeks before the foaming occurred, the crude protein concentration did not exceed $10 \mathrm{~g} / \mathrm{L}$. The crude protein content remained high after the foam has disappeared. The role of protein in foam formation has already been recognized by many authors (e.g. Ganidi et al. [6], Kougias et al. [14], and Clarke and Reid [31]).

The substrate charging in the period before, during, and after foaming is presented in Figure 2. There is a peak in the substrate feeding 2 weeks before foaming in the digester just as in the case of the foaming period described by Lienen et al. [5]. As the hydraulic retention time of the hydrolytic reactors was 11.2 days, the foamproducing agents reached the digesters during the second

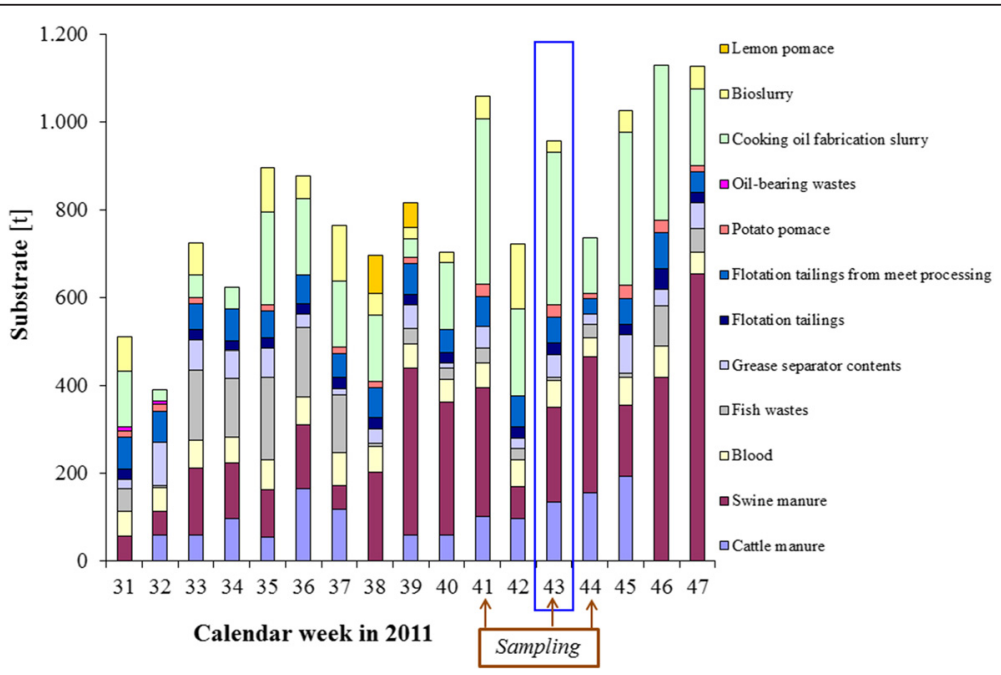

Figure 2 Substrate feeding before, during, and after the foaming period in BP A. The blue rectangle indicates the period when both digesters foamed. 


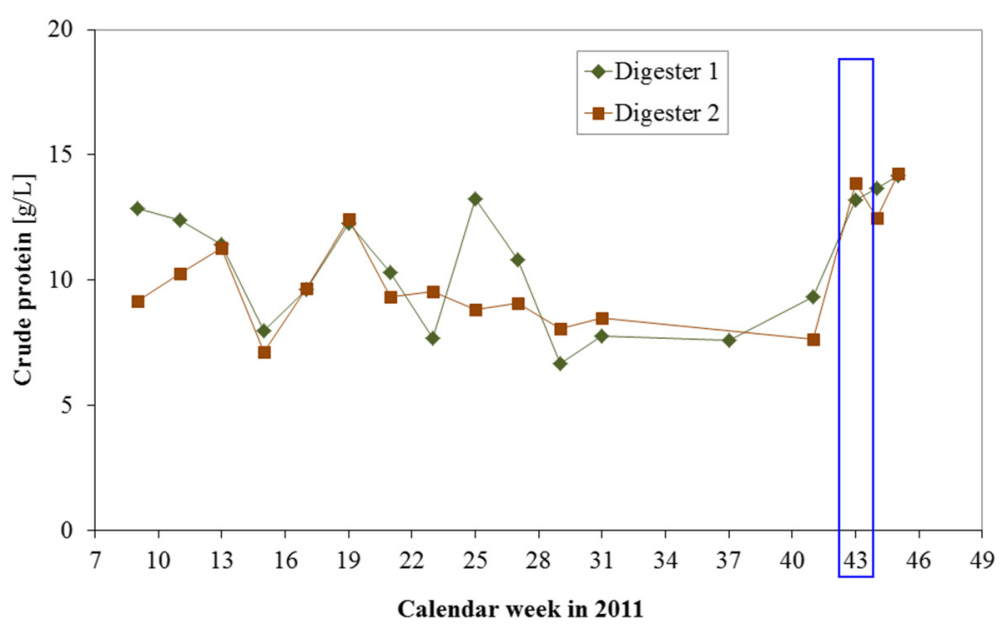

Figure 3 Crude protein concentrations before, during, and after the foaming period in BP A. The blue rectangle indicates the period when both digesters foamed.

week after their feeding into the biogas plant. The enhanced load during the 41st week may lead to an overload of the digester $\mathrm{AD}$. The overloading was detected as one of the most common causes of foaming in $\mathrm{AD}$ as described by Kougias et al. [14] and Ganidi et al. [33]. Nevertheless, the concentrations of volatile organic acids and other chemical parameters (Table 4) did not support the theory of overloading. Thus, it is plausible that the excessive foaming was a consequence of the sudden temperature increase. Three effects may have played a role in foam formation and stabilization in BP A. The first effect is the change in the solubility of gas at higher temperatures when large amounts of gases (mainly carbon dioxide) are released [34]. Secondly, a sudden change of cultivation conditions may lead to higher mortality of microbial cells as already has been described by Eder and Schulz [24]. This would explain the higher protein concentrations in the digestate as a consequence of cell decomposition. Thirdly, the enhanced addition of cooking oil in week 41 could contribute to foam stabilization. According to Kougias et al. [35], both gelatine and sodium oleate have formed foam in the $\mathrm{AD}$ of manure-based biogas reactors. This theory supports the steep increase in total organic carbon (TOC) concentration in digestate during the foaming period (Table 4). As the TOC content remained at high levels, its effect on foaming cannot be confirmed.

The most probable theory is that the temperature increase caused the release of high gas amounts, which have been stabilized by protein and oil that have been loaded in high amounts into the digester.

\section{Biogas plant BP B}

The two egg-shaped digesters of the biogas plant BP B originally served as digesters in a former wastewater treatment plant. Both digesters are connected together by using three overflows and can thus be operated as one tank due to the mixing of substrate by level adjustment during the feeding. The feed changed every $2 \mathrm{~h}$ from one digester to the other automatically.

The biogas plant operator often had problems with foam formation. Due to the egg shape of the digesters, the foam had not enough space in the headspace so that it tended to overflow. The foaming events were accompanied with high cleaning efforts as a consequence. According to the operator, the costs were estimated to be $€ 500$ to $€ 600$ for each foaming event. For this reason, both digesters were equipped with emergency overflows so that the foam can escape in the case of excessive foaming.

The biogas plant foamed regularly twice a week at the time of the first visit. The biogas plant operator identified dairy flushing water as the cause of the foam formation. The foam was reduced by the addition of plant oil. Three liters of rapeseed oil together with water were sprayed into the head space of the digesters. After performing this measure, the foam disappeared within a short time. Both the digestate and foam caused by loading of dairy flushing water were sampled and analyzed in August 2011.

In spring 2012, no more regular foaming was observed in BP B that could be connected with the loading of the digesters with dairy flushing water. The biogas plant operator believed that the reason for this was the stabilization of the fermentation material by the addition of old bread. Nevertheless, in February and mid-March, excessive foaming occurred that was definitely not associated with feeding the digesters with dairy flushing water. The operator supposed that the foam was caused by a particular charge of grease separator contents. However, the operator could 
not identify the real cause of strong foam formation. The grease separator content was sampled. Furthermore, several other samples of grease separator contents of various origins were withdrawn. The contents of water-soluble elements as well as the chloride concentration were analyzed as described in Table 2 in order to search for the causes of foaming.

The next excessive foaming event occurred in May 2012. The foam formation was accompanied by a considerable decrease of $50 \%$ in biogas production. This time, the grease separator content from a particular restaurant was suspected to be the cause of the problems. The biogas plant operator assumed that prohibited chloridecontaining disinfectants were used in the restaurant which entered into the grease separator contents. For this reason, the grease separator content was analyzed as described above. Furthermore, the digestate was sampled and analyzed as described in 'Analyses of foaming causes in full-scale fermenters'. This time, no foam was delivered by the operator to the laboratory.

The results of the analysis of foams and digestates are presented in Table 5, whereas the substrate charging during the foaming periods are shown in Figures 4 and 5.

The first sampling occurred in August 2011 after the addition of dairy flushing water. The difference in crude protein concentration in digestate $(15 \mathrm{~g} / \mathrm{L}$ protein) and foam $(2.8 \mathrm{~g} / \mathrm{L}$ protein $)$ showed that the foam was not formed by protein molecules. On the other hand, the total organic carbon content in foam increased. Propionate and butyrate were the only carbonic substances analyzed which had higher concentrations in the foam than in the digestate, but the VFA concentration measured by using the titration method (see VFA/TOC in Table 2) reached lower values in the foam than in the digestate $(1.34 \mathrm{~g} / \mathrm{L}$ in foam vs. $1.61 \mathrm{~g} / \mathrm{L}$ in digestate). Thus, it is highly probable that grease or its components played a certain role in foam formation and stabilization.

The causes of the foaming event in March 2012 were investigated. The separator content was analyzed regarding the elements which are soluble with water. The analysis data are shown in Table 6 in comparison with grease separator contents from other sources gained from BP B and from a canteen kitchen. The high variability in the content of elements especially in the case of calcium and potassium below the single samples is notable. Nevertheless, the analysis of the grease separator content, which was suspected to be a cause of foam formation, showed a slightly enhanced concentration of aluminum $(1.42 \mathrm{mg} / \mathrm{L})$ and zinc $(10.5 \mathrm{mg} / \mathrm{L})$. The effect of aluminum on biogas microbiology was studied by Cabirol et al. [36]. The authors found that this element inhibits bacterial activity. An addition of aluminum to the form of $1 \mathrm{~g} / \mathrm{L}$ aluminum hydroxide led to a reduction in microbial activity of $50 \%$ in the case of methanogenic microorganisms

Table 5 Analysis data of the digestates and foams of biogas plant BP B

\begin{tabular}{|c|c|c|c|c|c|c|c|c|}
\hline & & $\begin{array}{l}\text { Digestate } \\
\text { August } 2011\end{array}$ & Foam & $\begin{array}{l}\text { Digestate } \\
\text { April } 2012\end{array}$ & $\begin{array}{l}\text { Digestate } \\
\text { May } 2012\end{array}$ & $\begin{array}{l}\text { Digestate } \\
\text { June } 2012\end{array}$ & Foam & $\begin{array}{l}\text { Digestate } \\
\text { July } 2012\end{array}$ \\
\hline & Index & Foaming & & Foam-free & Foaming & Foaming & & Foam-free \\
\hline TS [\%] & $\mathrm{O}$ & 4.82 & 4.70 & 3.87 & 4.87 & n. d. & n. d. & 4.68 \\
\hline VS [\% TS] & $\mathrm{O}$ & 72.1 & 79.9 & 51.2 & 55.6 & 51.9 & 50.9 & 53.1 \\
\hline $\mathrm{pH}[-]$ & CE & 7.70 & 7.50 & 8.20 & 7.87 & 8.06 & 8.02 & 7.89 \\
\hline VFA/TIC [-] & CA & 0.19 & 0.24 & 0.14 & 0.18 & 0.16 & 0.17 & 0.20 \\
\hline $\mathrm{NH}_{4}-\mathrm{N}[\mathrm{g} / \mathrm{L}]$ & $F, S$ & $1.38(F)$ & $1.89(\mathrm{~F})$ & $1.58(\mathrm{~S})$ & $2.55(\mathrm{~S})$ & n. d. & n. d. & $3.95(F)$ \\
\hline Total organic carbon [g/L] & B & 11.1 & 13.7 & 17.0 & 20.6 & 12.8 & 8.62 & 14.0 \\
\hline Total nitrogen [g/L] & B & 3.77 & 2.36 & 5.43 & 8.81 & 5.86 & 5.12 & 6.36 \\
\hline Crude protein $[\mathrm{g} / \mathrm{L}]$ & CA & 14.9 & 2.83 & 24.0 & 39.1 & n. d. & n. d. & 15.0 \\
\hline Acetic acid [mg/L] & $\mathrm{F}$ & 583 & 564 & 16.9 & 601 & 446 & 71.0 & 1,061 \\
\hline Propionic acid [mg/L] & $\mathrm{F}$ & 63.5 & 162 & 0 & 81 & 17.6 & 0 & 125.9 \\
\hline Butyric acid [mg/L] & $\mathrm{F}$ & 0 & 39.6 & 0 & 0 & 0 & 0 & 13.8 \\
\hline Calcium [mg/L] & $\mathrm{F}$ & 85.2 & 38.8 & 97.1 & 119 & 67 & 31.6 & 158 \\
\hline Iron [mg/L] & $\mathrm{F}$ & 4.42 & 4.69 & 14.1 & 4.44 & 5.82 & 5.02 & 6.00 \\
\hline Magnesium [mg/L] & $\mathrm{F}$ & 10.1 & 7.02 & 15.8 & 34.2 & 11.7 & 29.0 & 39 \\
\hline Nickel [mg/L] & $\mathrm{F}$ & $<2$ & $<2$ & 8.71 & $<0.8$ & $<0.8$ & $<0.8$ & 2.4 \\
\hline Phosphorus [mg/L] & $\mathrm{F}$ & 12.8 & 19.7 & 70.4 & 68.8 & 38.4 & 6.92 & 47.4 \\
\hline Potassium [mg/L] & $\mathrm{F}$ & 1,700 & 1,190 & 1,602 & 1,606 & 1,500 & 1,546 & 1,762 \\
\hline Sulfur [mg/L] & $\mathrm{F}$ & 30.8 & 28.2 & 59.2 & 62.2 & 33.8 & 33.6 & 38.6 \\
\hline
\end{tabular}




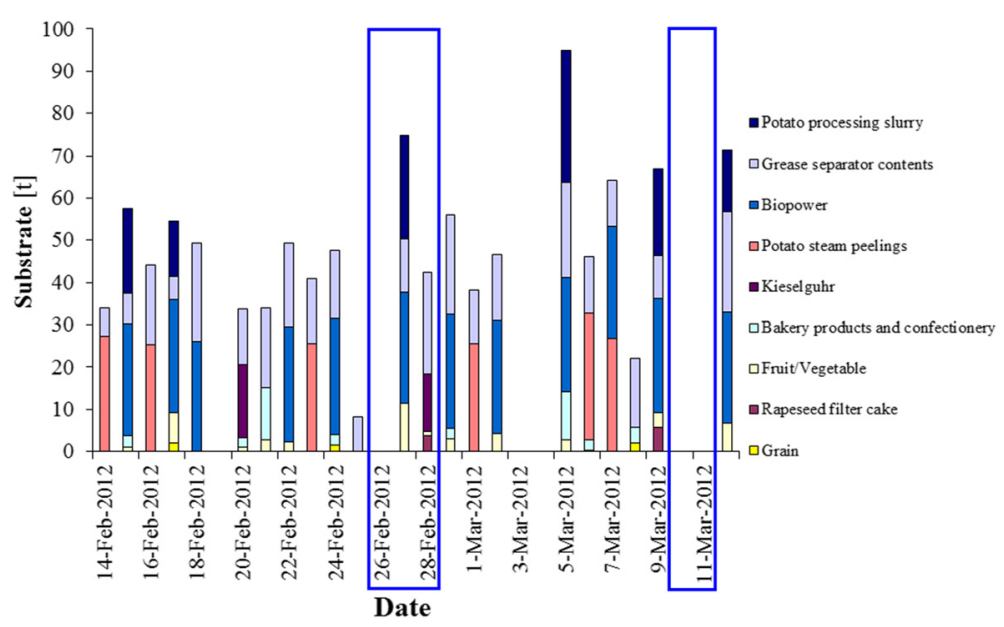

Figure 4 Substrate supplies in biogas plant BP B during February and March 2012. The blue rectangles indicate the foaming events.

and of $72 \%$ in the case of acetogenic bacteria. The aluminum concentration in the grease separator content was indeed much lower at a value of $1.42 \mathrm{mg} / \mathrm{L}$. Zinc also has an inhibitory effect on anaerobic digestion - in concentrations from $400 \mathrm{mg} / \mathrm{L}$ in the form of free ions and from $160 \mathrm{mg} / \mathrm{L}$ as zinc carbonate [37]. However, it is questionable whether the contents of both elements can cause negative effects after dilution in the digesters.

The investigation of the causes of foaming also included the analysis of the substrate supplies to the biogas plants during February and March (Figure 4). It is noticed that grain and bakery products were delivered 2 days before foaming. 'Grain' means grain sieve wastes that contained grain corn as well as coarse grain milled at various degrees of milling coarseness. Moeller et al. [38] described foam formation in the anaerobic digestion process due to the loading with coarse grain. The milling coarseness played a crucial role in the foaming propensity of grain: the finer the grain was milled, the higher was the foam content in the foaming tests. Moreover, Moeller et al. [32] demonstrated that sucrose can also cause foaming in AD. Thus, it is very possible that the combination of these two components caused excessive foaming in the biogas plant BP B.

The analyses of the suspicious grease separator content showed no abnormalities as compared to other substrate samples (Table 6). Only the calcium concentration at $210 \mathrm{mg} / \mathrm{L}$ was somewhat higher than in the case of the majority of the samples. The analysis of chloride content showed that the chloride concentration in this grease separator content of $120 \mathrm{mg} / \mathrm{L}$ was the lowest of all of the tested substrates (Table 7). On the other hand, the chloride concentration in the digestate was higher at the time of foam formation than in older samples.

Considering the substrate supplies in May 2012, the delivery of baker's yeast before the foaming event is

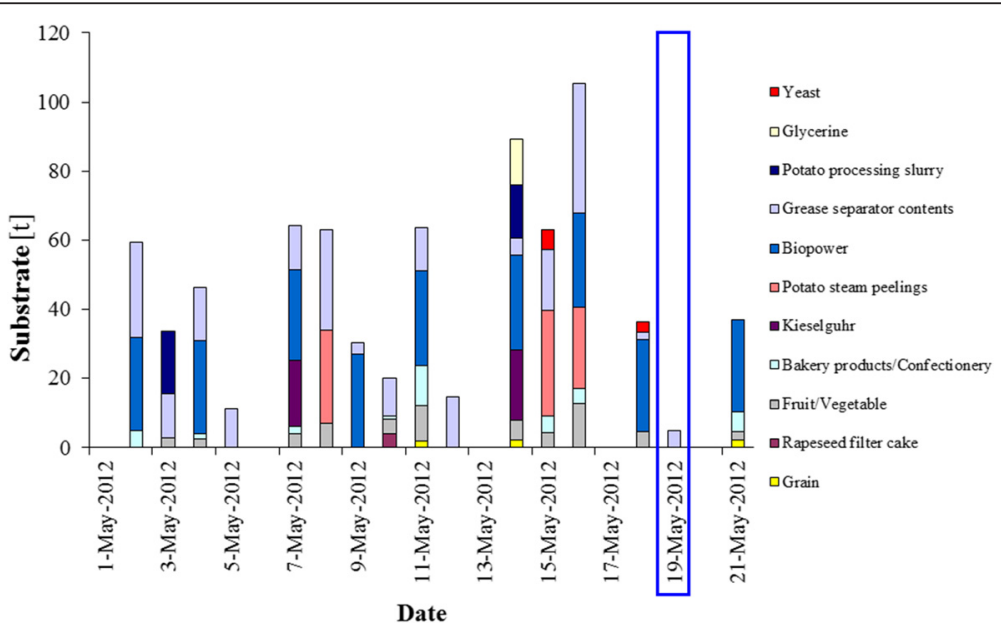

Figure 5 Substrate supplies in biogas plant BP B during May 2012. The blue rectangle indicates the foaming event. 
Table 6 Water soluble elements in grease separator contents used as substrate in BP B

\begin{tabular}{|c|c|c|c|c|c|}
\hline & \multicolumn{4}{|c|}{ Grease separator contents used at biogas plant BP B } & \multirow{2}{*}{$\begin{array}{l}\text { Grease separator content } \\
\text { from a canteen kitchen }\end{array}$} \\
\hline & March 2012 (foaming event) & May 2012 (foaming event) & 4th June 2012 & 18th June 2012 & \\
\hline Aluminum $[\mathrm{mg} / \mathrm{L}]$ & 1.42 & $<1.2$ & $<1.2$ & $<1.2$ & $<1.2$ \\
\hline Calcium [mg/L] & 125 & 210 & 67.0 & 586 & 6.67 \\
\hline Iron [mg/L] & 16.9 & $<0.6$ & 5.82 & 37.8 & 1.53 \\
\hline Magnesium [mg/L] & 18.8 & 41.0 & 11.7 & 80.4 & 6.37 \\
\hline Manganese [mg/L] & $<0.2$ & $<0.2$ & $<0.2$ & 2.32 & $<0.2$ \\
\hline Phosphorus [mg/L] & 31.7 & 66.6 & 38.4 & 130 & 14.6 \\
\hline Potassium [mg/L] & 52.8 & 77.8 & 1,500 & 143 & 28,2 \\
\hline Sulfur [mg/L] & 26.1 & 46.6 & 33.8 & 53.2 & 39.4 \\
\hline Zinc [mg/L] & 10.5 & $<1.2$ & $<1.2$ & $<1.2$ & $<1.2$ \\
\hline
\end{tabular}

Grease separator content from a canteen kitchen served as reference.

noteworthy (Figure 5). It is known that yeast supports foam formation [39]. For this reason, yeast is normally loaded in small amounts into the digester. Nevertheless, in this case, an employee at BP B was inattentive and loaded two pallets of yeasts into the substrate storage container at once.

\section{Biogas plant BP C}

The characteristics of biogas plant BP $\mathrm{C}$ have already been published in [11]. The four digesters were operated in cascades (digesters D1 and D3 in one line, digesters D2 and D4 in the second line). A mixture of primary sludge and surplus sludge served as the substrate for biogas production and was fed into the digesters D1 and D3. In addition, grease separator contents were fed into one of the digesters (D3).

Foam formation was detected in digester D3, where grease separator contents were co-digested over a period of 2 months (December 2009 and January 2010). The digesters D1, D2, and D3 were sampled at the time of foam occurrence in digester D3. Additionally, the foam was sampled in the overrun of the foaming digester. The samples were analyzed as described in Analyses of

Table 7 Chloride concentrations in samples of grease separator contents and digestates from the biogas plant BP B

\begin{tabular}{lll}
\hline & Date & Chloride [mg/L] \\
\hline $\begin{array}{l}\text { Grease separator content } \\
\text { (origin: foaming BP B) }\end{array}$ & March 2012 & 191 \\
$\begin{array}{l}\text { Grease separator content } \\
\text { (origin: foaming BP B) }\end{array}$ & May 2012 & 120 \\
$\begin{array}{l}\text { Grease separator content } \\
\text { (origin: restaurant in Saxony); } \\
\text { serves as reference }\end{array}$ & May 2012 & 607 \\
$\begin{array}{l}\text { Digestate (origin: foaming BP B) } \\
\text { Digestate (origin: non-foaming BP B) }\end{array}$ & November 2011 & 2,420 \\
$\begin{array}{l}\text { Digestate (origin: non-foaming BP B) } \\
\text { November 2011 }\end{array}$ & 2,370 \\
\hline
\end{tabular}

foaming causes in full-scale fermenters'. Unlike the analysis of samples of the other biogas plants, the fatty acid patterns were analyzed in digestates and foams from all digesters. This analysis was performed in order to identify the influence of the grease separator contents on the digestate composition and to determine the foam-forming compounds.

The analysis data of the digestate and foam samples are summarized in Table 8 . The digestate from the foaming

Table 8 Analysis data of samples of the biogas plant BP C

\begin{tabular}{|c|c|c|c|c|c|}
\hline & \multirow[b]{2}{*}{ Index } & \multirow{2}{*}{$\begin{array}{l}\text { Digester D1 } \\
\text { Digestate }\end{array}$} & \multirow{2}{*}{$\begin{array}{l}\text { Digester D2 } \\
\text { Digestate }\end{array}$} & \multicolumn{2}{|c|}{ Digester D3 } \\
\hline & & & & Digestate & Foam \\
\hline TS [\%] & $\mathrm{O}$ & 3.55 & 3.44 & 3.20 & 3.43 \\
\hline VS [\% TS] & O & n. d. & 69.3 & 69.8 & 70.7 \\
\hline $\mathrm{pH}[-]$ & CE & 7.33 & 7.24 & 7.36 & 7.64 \\
\hline VFA/TIC [-] & CA & 0.05 & 0.06 & 0.08 & 0.06 \\
\hline $\mathrm{NH}_{4}-\mathrm{N}[\mathrm{g} / \mathrm{L}]$ & F & 0.86 & 0.94 & 0.99 & 1.20 \\
\hline $\begin{array}{l}\text { Total organic } \\
\text { carbon [g/L] }\end{array}$ & CE & 1.20 & 1.11 & 2.13 & 1.22 \\
\hline $\begin{array}{l}\text { Total nitrogen } \\
{[\mathrm{g} / \mathrm{L}]}\end{array}$ & CE & 1.54 & 1.46 & 2.01 & 1.81 \\
\hline Acetate [mg/L] & F & 2.2 & 21 & 30 & 59 \\
\hline $\begin{array}{l}\text { Propionate } \\
{[\mathrm{mg} / \mathrm{L}]}\end{array}$ & $\mathrm{F}$ & $<1$ & 5.5 & 3.6 & 10 \\
\hline Butyrate [mg/L] & $\mathrm{F}$ & $<1$ & $<1$ & $<1$ & $<1$ \\
\hline $\begin{array}{l}\text { Palmitic } \\
\text { acid [\%] }\end{array}$ & E & 36.8 & 39.2 & 28.4 & 27.7 \\
\hline Stearic acid [\%] & $\mathrm{E}$ & 28.7 & 29.9 & 19.8 & 19.3 \\
\hline Oleic acid [\%] & $E$ & 21.7 & 18.1 & 43.5 & 43.2 \\
\hline $\begin{array}{l}\text { Linoleic } \\
\text { acid [\%] }\end{array}$ & E & 10.9 & 9.6 & 5.8 & 6.8 \\
\hline $\begin{array}{l}\text { Linolenic } \\
\text { acid [\%] }\end{array}$ & $E$ & 1.9 & 3.2 & 2.5 & 2.9 \\
\hline $\begin{array}{l}\text { Surface tension } \\
{[\mathrm{mN} / \mathrm{m}]}\end{array}$ & CE & 72 & 72 & 71 & 71 \\
\hline
\end{tabular}

Taken on 14th December 2009. 
digester had the highest VFA/TIC of 0.08 , but the VFA/ TIC values were in general very low in all digestates, when compared with samples from other biogas plants (e.g. Tables 4 and 5). The concentrations of ammoniumnitrogen and acetate, propionate, and butyrate were also comparatively low. The low VFA content shows that over-acidification can be excluded as the foaming cause in D3.

On the contrary, the concentrations of TOC, TN, and oleic acid were higher in digester D3 when compared to digesters D1 and D2, which can be traced back to the feeding of grease separator contents into D3.

Comparing the data of foam and digestate of D3, a slight accumulation of ammonium-nitrogen, acetate, and propionate in the foam fraction was observed. However, the content of long-chain fatty acids was not higher in the foam fraction, so it can be concluded that the foam was not produced or stabilized solely by the components of the grease separator contents. For this reason, the foam of D3 was evaluated under the microscope. This measure ultimately proved to be effective, as filamentary microorganisms were found to be responsible for foam formation in D3 (Figure 6a). Further closer microbiological analyses, including genetic fingerprinting and quantitative PCR (qPCR), have been carried out at the German Research Centre for Geosciences and are described by Lienen et al. [11]. The authors found that a higher abundance of the filamentous bacterium Microthrix parvicella occurred in D3 during two foaming periods than in both digesters D1 and D2.

\section{Biogas plant BP D}

The biogas plant BP D was visited for the first time within the scope of the survey of biogas plant operations. There were no problems with foaming at that time. The biogas plant operator stated that there was long-term foaming in the start-up stage, when biogas production also declined simultaneously. This problem was solved by adding a nutrient solution.

One year after the first visit, the biogas plant operator reported about excessive foam formation. According to the operator, several events occurred before foaming appeared: a new method of digestate processing was tested during full-load operation. The digestate was separated into liquid and solid phases; the solid phase was fed back into the digester. Changes in the digestate color from a light to a dark tone were observed during this phase. In addition, the wastewater treatment plant had been rebuilt with the aim of improving the dewatering of the sewage sludge. As a side effect of this, the phosphate concentration in the sewage sludge that was fed into the biogas plant was increased. After the implementation of the new technologies, the biogas plant started to foam. This problem was combated by a starvation diet and by
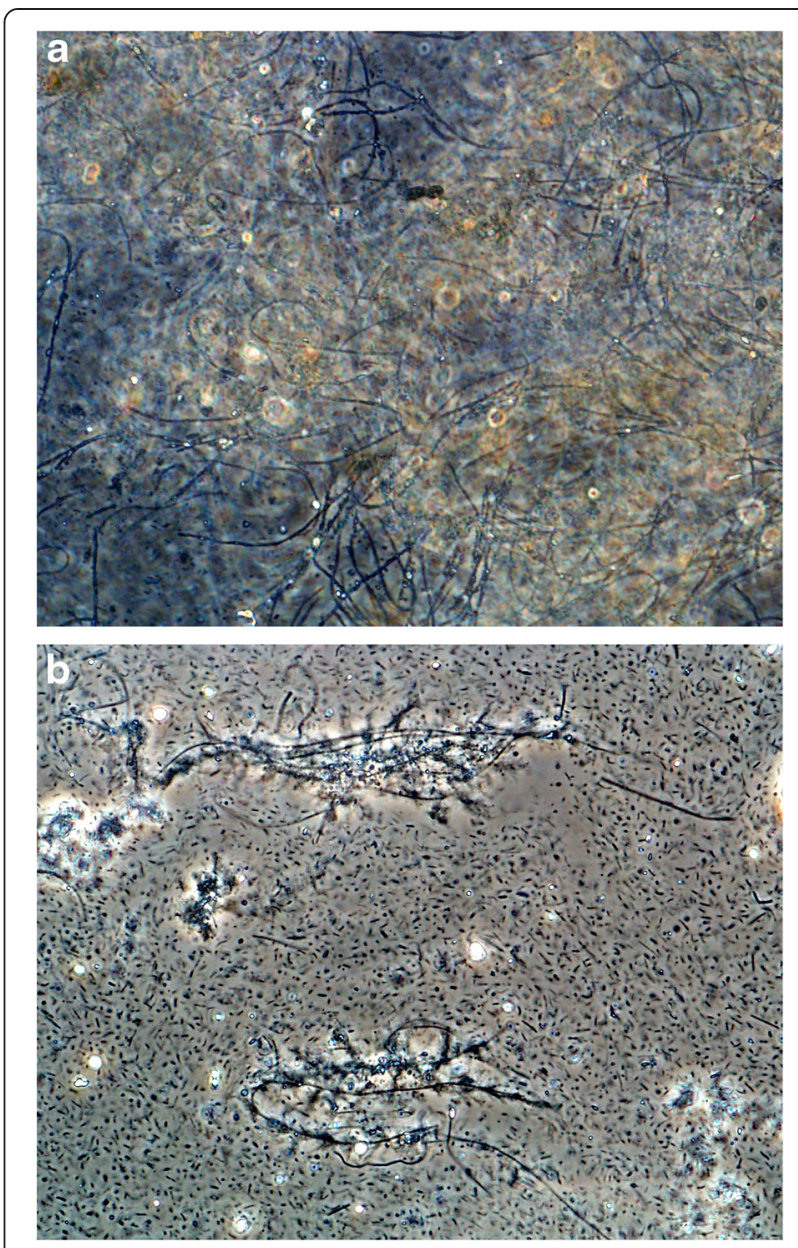

Figure 6 Filamentous microorganisms in foam. Filamentous microorganisms in foam from digester D3 of the biogas plant BP C (200x magnification) (a) and from the biogas plant BP D (400X magnification) (b).

pumping water into the digester. Unfortunately, the latter measure led to a considerable reduction in temperature of more than $10 \mathrm{~K}$ inside of the digester. The subsequent foaming was so strong that the foam overflowed. The biogas plant operator sampled the digestate and foam twice in an interval of 1 month and delivered the samples to the laboratory for analysis.

As the foaming problem was very serious, the biogas digester content had to be pumped out and the $\mathrm{AD}$ process had to be restarted.

The analysis data of these samples are displayed in Table 9. The acetate concentration in digestate was 95 and $109 \mathrm{mg} / \mathrm{L}$ showing a balanced AD [30]. The ammoniumnitrogen content in both digestates was lower than in all other biogas plants investigated in this study. For this reason, there was no indicating device for a disturbance of the AD.

The foaming cause could be the temperature fluctuations as reported in the case of BP A. According to Eder 
Table 9 Analysis data of samples from the biogas plants BP D and BP E

\begin{tabular}{|c|c|c|c|c|c|c|c|c|c|}
\hline \multirow[b]{4}{*}{ TS [\%] } & \multicolumn{5}{|c|}{ Biogas plant BP D } & \multicolumn{4}{|c|}{ Biogas plant BP E } \\
\hline & \multirow[b]{2}{*}{ Index } & Digestate & Foam & Digestate & Foam & \multirow[b]{2}{*}{ Index } & Substrate & Digestate & \multirow[t]{2}{*}{ Recirculate } \\
\hline & & \multicolumn{2}{|c|}{$\begin{array}{l}\text { First sampling } \\
\text { (17th July 2012) }\end{array}$} & \multicolumn{2}{|c|}{$\begin{array}{l}\text { Second sampling } \\
\text { (27th August 2012) }\end{array}$} & & \multicolumn{2}{|c|}{ 8th September 2011} & \\
\hline & $\mathrm{O}$ & 2.17 & 1.60 & 1.98 & 1.93 & $\mathrm{O}$ & 14.3 & 10.7 & 8.08 \\
\hline VS [\% TS] & $\mathrm{O}$ & 72.2 & 69.4 & 63.8 & 74.4 & $\mathrm{O}$ & 69.5 & 77.0 & 76.3 \\
\hline $\mathrm{pH}[-]$ & S & 7.93 & 8.22 & 7.96 & 8.67 & CE & 8.23 & 7.18 & 8.10 \\
\hline VFA/TIC [-] & CA & 0.24 & 0.19 & 0.16 & 0.20 & CA & 1.39 & 0.16 & 0.20 \\
\hline $\mathrm{NH}_{4}-\mathrm{N}[\mathrm{g} / \mathrm{L}]$ & $\mathrm{F}$ & 0.55 & 0.33 & 0.64 & 0.67 & $\mathrm{~F}$ & 5.05 & 4.01 & 4.07 \\
\hline Total organic carbon $[\mathrm{g} / \mathrm{L}]$ & S & 3.69 & 4.33 & 6.12 & 5.76 & B & 43.5 & 30.9 & 28.6 \\
\hline Total nitrogen [g/L] & S & 1.03 & 1.23 & 1.81 & 1.68 & B & 7.78 & 8.63 & 6.62 \\
\hline Crude protein [g/L] & CA & 2.99 & 5.65 & 7.36 & 6.30 & CA & 16.6 & 28.5 & 15.5 \\
\hline Acetate [mg/L] & $\mathrm{F}$ & 95 & 27.9 & 109 & 30 & $\mathrm{~F}$ & 1,762 & 143 & 51.6 \\
\hline Propionate [mg/L] & $\mathrm{F}$ & $<1$ & $<1$ & 15.7 & $<1$ & $\mathrm{~F}$ & 868 & 7.60 & 0 \\
\hline Butyrate [mg/L] & $\mathrm{F}$ & $<1$ & $<1$ & $<1$ & $<1$ & $\mathrm{~F}$ & 313 & 0 & 0 \\
\hline Calcium [mg/L] & $\mathrm{F}$ & 40.8 & 45.8 & 53.8 & 46.2 & $\mathrm{~F}$ & 91.8 & 221 & 112 \\
\hline Iron [mg/L] & $\mathrm{F}$ & 1.08 & 1.18 & 2.12 & 1.48 & $\mathrm{~F}$ & 17.0 & 11.0 & 15.5 \\
\hline Potassium [mg/L] & $F$ & 2,140 & 2,220 & 2,560 & 2,500 & $\mathrm{~F}$ & 3.98 & 4.08 & 4.70 \\
\hline Magnesium [mg/L] & $F$ & 11.6 & 9.82 & 12.6 & 7.94 & $F$ & 211 & 84.8 & 139 \\
\hline Manganese [mg/L] & F & 0.36 & 0.34 & 0.94 & 0.74 & F & $<0.5$ & $<0.5$ & $<0.5$ \\
\hline Phosphorus [mg/L] & $\mathrm{F}$ & 47.8 & 42.6 & 66.6 & 51.2 & $\mathrm{~F}$ & 138.9 & 210.5 & 84.8 \\
\hline Potassium [mg/L] & $\mathrm{F}$ & 2.140 & 2.220 & 2.560 & 2.500 & $\mathrm{~F}$ & 3,905 & 3,775 & 3,085 \\
\hline Sulfur [mg/L] & $\mathrm{F}$ & 14.0 & 23.6 & 18.4 & 24.2 & $\mathrm{~F}$ & 117 & 106 & 110 \\
\hline Surface tension $[\mathrm{mN} / \mathrm{m}]$ & & n. d. & n. d. & n. d. & n. d. & CE & 53.6 & 55.5 & n. d. \\
\hline
\end{tabular}

and Schulz [24], sudden temperature changes of more than $1 \mathrm{~K}$ are very problematic, especially for thermophile biogas processes. Moreover, one other aspect was assumed to play a role in the foaming of BP D. Because the biogas plant was loaded with sewage sludge rich in phosphate, among other components, it was suspected that filamentous microorganisms could play a role in foam stabilization as described by Pagilla et al. [8], Lienen et al. [11], and Westlund et al. [9]. A microscopic inspection of foam did indeed show a lot of filamentous structures (Figure 6b) which could probably be the foam-forming agents in this case.

\section{Biogas plant $B P E$}

The biogas plant BP E had major problems with foaming. Foam was formed at all its process stages. The biogas plant operator did not use anti-foaming agents to remove the foam because no success had been achieved with the commercial defoamers. Thus, all stages were equipped with stirrers that operated continuously. Even the digestate storage had to be stirred continuously to avoid over-foaming.

The substrate mixture, the digestate, and the recirculate were sampled and analyzed (Table 9). The ammonium- nitrogen concentration in the samples was very high; even in the recirculate $4.07 \mathrm{~g} / \mathrm{L} \mathrm{NH}_{4}-\mathrm{N}$ was measured. The reason for this lies in the digestion of the grain husk in high amounts. On the other hand, the concentration of acetate showed a balanced digestion process as described by Hill et al. [30]. The surface tension was lower here than in samples of all other biogas plants described in this paper.

As the $\mathrm{NH}_{4}-\mathrm{N}$ concentration was very high, the ammonia inhibition of the AD process can be assumed. Kroiss [40] showed in laboratory experiments that there has occurred a beginning limitation of the $\mathrm{AD}$ at ammonium concentrations of $3 \mathrm{~g} / \mathrm{L}$. On the other side, Chen et al. [23] demonstrated that there are many different data addressing the inhibitory effect of the total ammonia concentration in the AD ranging from 1.7 to $14 \mathrm{~g} / \mathrm{L}$. The authors also described an effect of acclimatization of the AD microbiology on high ammonia concentrations. Eder and Schulz [27] reported that the ammonia inhibition is often accompanied by a strong foaming. They suspected that the foam formation is caused by protein-degrading compounds. Furthermore, they showed that the recirculation of the digestate can cause an accumulation of ammonium in the digester. In fact, in the BP E phase, the separation of the digestate is carried out and the liquid phase aimed 
at mashing the substrate. No ammonia stripping is carried out. On the other side, the low VFA concentrations do not strengthen the view that an inhibition of ammonia has started.

The foam formation is a common phenomenon in grain AD as described in Moeller et al. [38]. The authors reported that triticale and wheat formed more foam than rye, barley, and oats. The measured ammonium concentration of $2 \mathrm{~g} / \mathrm{L}$ was not as high as in BP E. Both protein and starch were identified to be the foam-forming agents.

For this reason, it can be presumed that the strong foaming in BP E is caused by the digestion of grain waste products and the ammonia inhibition may not be assumed being the direct foaming cause in this case. Nevertheless, more investigations will be required to define the most proper foaming mitigation strategy for this biogas plant.

\section{Importance of the results for the research of foaming causes in full-scale reactors}

The survey of biogas plant operators showed that foam formation is a well-known phenomenon in fullscale biogas plants. Only little information was given by biogas plant operators about the costs for foaming. Excessive foaming can have serious economical consequences as described in 'Survey of foam formation in full-scale biogas plants'. On the other side, the costs can be limited to several hundred euros. According to the operator of $\mathrm{BP} \mathrm{B}$, the costs were estimated to be several hundred euros for each foaming event. However, the operators do not mostly know the real costs of a foaming event if no damage of biogas plant devices occurred.

The closer analysis of foaming events in five biogas plants further revealed that the search for foaming causes is often a very hard job as many factors may play a role. For example, physical effects such as temperature fluctuations are accompanied by foaming (BP A). Moreover, the composition of the substrate mix is of high importance as substrates containing proteins (BP B and $\mathrm{BP} E$ ), grease (BP B), and filamentous microorganisms (BP C and BP D) were identified as foaming causes. The physicochemical analyses used in this study confirmed that the most common indicators of unbalanced AD did not indicate a process failure in the majority of foaming events. On the other side, the analyses of the foam and digestate compositions contributed to the indication of foaming causes. Unfortunately, the foam cannot be sampled in most of the biogas digesters as no access to the digestate surface is possible.

This study showed that the laboratory analyses have to be completed by the operational data of the biogas plants in the search for the causes of foaming. Primarily, the substrate loading diagram is a very important support.
Apart from that, the use of batch foaming tests as described by Moeller et al. [19] may be helpful. This method is suitable for both laboratory research and for on-side estimation of the foaming propensity of substrates. As the filamentous microorganisms are well visible under the microscope, the microscopic observation of foam may also assist the examination of foaming causes. In this way, the biogas plant operators are able to identify the most foaming causes by themselves. After that, they can apply some of mitigation strategies that are suitable for the specific foaming cause. As an example, in the case of the foaming due to the presence of filamentous microorganisms, methods of ultrasonic pre-treatment of feeding sludge were developed by Barjenbruch et al. [10]. However, new methods of foaming mitigation have to be developed for the use of 'risky' substrates like for example grain and yeast.

\section{Conclusions}

This study displayed a high frequency of foaming events and identified the main causes of foaming in full-scale biogas plants. A survey of biogas plant operators in three German federal states showed that $80 \%$ of biogas plants had problems with foaming. A closer analysis of foaming events in five biogas plants enabled the identification of the causes of foaming in five cases. In general, a correlation was found between the use of substrates for biogas production and foam formation. The foamprovoking substrate mixtures contained not only grain, bakery, and confectionery products but also yeasts and filamentous microorganisms. Furthermore, sudden temperature increases by $3 \mathrm{~K}$ had provoked foaming in one biogas plant. While excessive foaming is a frequent phenomenon that often has serious consequences for biogas plants, the causes of foaming usually remain unidentified in practical applications. In addition, it was not possible to determine the reasons for foaming in our research in some cases. Foam formation in the anaerobic digestion process has begun to attract increasing attention within the context of the improvement of the efficiency of the entire biogas production process. This is the first publication concerning the establishment of the causes of foaming in full-scale biogas plants which process biogenic waste that shows an abundance of factors playing a role in foam formation and stabilization based on real data.

The next research study should focus on foaming mitigation strategies in full-scale fermenters to explore the effects of specific substrates as for example on grain AD. In addition, new methods of substrate pre-treatment before its loading into the fermenter should be developed in order to prevent the foam formation in biogas digesters. 


\section{Abbreviations}

BP: biogas plant; CA: calculated; CE: centrifuged; D: digester; E: extracted; F: filtered; IC: inorganic carbon; O: origin sample; P: pureed sample; S: sieved sample; TC: total carbon; TIC: total inorganic carbonate buffer; TOC: total organic carbon; TN: total nitrogen; TS: total solid content; VS: volatile solid content; VOA: volatile organic acids.

\section{Competing interests}

The authors declare that they have no competing interests.

\section{Authors' contributions}

LM led the project, collected and sorted the publication and information material, and prepared the manuscript. KG surveyed the operators, analyzed the samples, contributed with critical reading of the manuscript, and provided input for the final version. Both authors read and approved the final manuscript.

\section{Acknowledgements}

This project was funded by the German Federal Ministry for the Environment, Nature Conservation and Nuclear Safety on the basis of a decision of the German Bundestag and the Initiating and Networking Fund of the Helmholtz Association. The authors would like to thank all the biogas plant operators who provided us with substrates and fermentation material. The authors would also like to extend their best wishes to Prof. Dr.-Ing. Andreas Zehnsdorf on the occasion of his 50th birthday.

\section{Received: 17 June 2014 Accepted: 11 December 2014}

\section{Published online: 17 January 2015}

\section{References}

1. German Biogas Association (2011) Fachverband Biogas e. V. Biogas Branchenzahlen. Freising, Germany, http://www.biogas.org/edcom/webfvb. nsf/id/DE_Branchenzahlen/\$file/14-11-25_Biogas\% 20Branchenzahlen_Prognose_2014-2015.pdf. Accessed 21 May 2014

2. Bundesministerium für Wirtschaft und Energie (2014) Erneuerbare Energien 2013. Daten der Arbeitsgruppe Erneuerbare Energien-Statistik (AGEE-Stat). http://www.erneuerbare-energien.de/EE/Redaktion/DE/Downloads/ bmwi_de/ee_flyer_2013.html. Accessed 24 July 2014

3. Kleyböcker A, Liebrich M, Kasina M, Kraume M, Wittmaier M, Würdemann H (2012) Comparison of different procedures to stabilize biogas formation after process failure in a thermophilic waste digestion system: influence of aggregate formation on process stability. Waste Manag 32(6):1122-30

4. Kleyböcker A, Liebrich M, Verstraete W, Kraume M, Würdemann H (2012) Early warning indicators for process failure due to organic overloading by rapeseed oil in one-stage continuously stirred tank reactor, sewage sludge and waste digesters. Bioresour Technol 123:534-41

5. Lienen T, Kleyböcker A, Brehmer M, Kraume M, Moeller L, Görsch K, Würdemann H (2013) Floating layer formation, foaming, and microbial community structure change in full-scale biogas plant due to disruption of mixing and substrate overloading. Energ Sustain Soc 3:20

6. Ganidi N, Tyrrel S, Cartmell E (2009) Anaerobic digestion foaming causes - a review. Bioresource Technol 100:5546-5554

7. Pujol R, Duchene P, Schetrite S, Canler JP (1991) Biological foams in activated sludge plants: characterization and situation. Wat Res 25:1399-1404

8. Pagilla KR, Craney KC, Kido WH (1997) Causes and effects of foaming in anaerobic sludge digesters. Wat Sci Tech 36:463-470

9. Westlund ÅD, Hagland E, Rothman M (1998) Foaming in anaerobic digesters caused by Microthrix parvicella. Wat Sci Tech 37:51-55

10. Barjenbruch M, Hoffmann H, Kopplow O, Tränckner J (2000) Minimizing of foaming in digesters by pre-treatment of the surplus-sludge. Wat Sci Tech 42:235-241

11. Lienen T, Kleyböcker A, Verstraete W, Würdemann H (2014) Foam formation in a downstream digester of a cascade running full-scale biogas plant: influence of fat, oil and grease addition and abundance of the filamentous bacterium Microthrix parvicella. Bioresource Technol 153:1-7

12. Kougias PG, Tsapekos P, Boe K, Angelidaki I (2013) Antifoaming effect of chemical compounds in manure biogas reactors. Wat Res 47:6280-6288

13. Kougias PG, Boe K, Tsapekos P, Angelidaki I (2014) Foam suppression in overloaded manure-based biogas reactors using antifoaming agents. Bioresource Technol 153:198-205
14. Kougias PG, Boe K, O-Thong S, Kristensen LA, Angelidaki I (2014) Anaerobic digestion foaming in full-scale biogas plants: a survey on causes and solutions. Water Sci Technol 69:889-895

15. Moeller L, Görsch K, Neuhaus J, Zehnsdorf A, Müller RA (2012) Comparative review of foam formation in biogas plants and ruminant bloat. Energ Sustain Soc 2:12

16. Stoyanova E, Forsthuber B, Pohn S, Schwarz C, Fuchs W, Bochmann G (2014) Reducing the risk of foaming and decreasing viscosity by two-stage anaerobic digestion of sugar beet pressed pulp. Biodegradation 25:277-289

17. Suhartini S, Heaven S, Banks CJ (2014) Comparison of mesophilic and thermophilic anaerobic digestion of sugar beet pulp: performance, dewaterability and foam control. Bioresource Technol 152:202-211

18. Moeller L, Görsch K, Müller RA, Zehnsdorf A (2012) Formation and suppression of foam in biogas plants - practical experiences. Agricultural Engineering (Landtechnik) 67(2):110-113

19. Moeller L, Köster Y, Zehnsdorf A. (2013a) LEIPZIGER SCHAUMTESTER Testset zur Bestimmung der Schaumneigung von Substrat im aktiven Gärmaterial (S. 99-102). in Messmethodensammlung Biogas, 2nd edn. Script series of the support programme 'Biomass for Energy' Volume 7. ISSN 2192-1806

20. Bligh EG, Dyer WJ (1959) A rapid method of total lipid extraction and purification. Can J Biochem Phys 37:911-917

21. Morrison WR, Smith LM (1964) Preparation of fatty acid methyl esters and dimethylacetals from lipids with boron fluoride-methanol. J Lipid Res 5:600-608

22. Switzenbaum MS, Giraldo-Gomez E, Hickey RF (1990) Monitoring of the anaerobic methane fermentation process. Enzyme Microb Technol 12:722-730

23. Chen Y, Cheng JJ, Creamer KS (2008) Inhibition of anaerobic digestion process: a review. Bioresource Technol 99:4044-4064

24. Eder B, Schulz H (2007) Der Biogas-Prozess, in Biogas Praxis, 4th edn. Staufen bei Freiburg, Ökobuch-Verlag, pp 19-40

25. Wang Y, Majak W, McAllister T (2012) Frothy bloat in ruminants: cause occurrence, and mitigation strategies. Anim Feed Sci Technol 172:103-114

26. Miltimore JE, McArthur JM, Mason JL, Ashby DL (1970) Bloat investigations. The threshold fraction 1 (18S) protein concentration for bloat and relationships between bloat and lipid, tannin, $\mathrm{Ca}, \mathrm{Mg}, \mathrm{Ni}$ and $\mathrm{Zn}$ concentrations in alfalfa. Can J Anim Sci 50:61-68

27. Burchard CH, Groche D, Zerres HP (2001) ATV Handbuch einfacher Messungen und Untersuchungen auf Klärwerken, 10th edn. Hirthammer Verlag, München

28. Moeller L, Görsch K, Ramhold D, Kielhorn E (2013b) Bestimmung der organischen Säuren, in Messmethodensammlung Biogas, 2nd edn. Script series of the support programme 'Biomass for Energy' Volume 7. pp. 36-39. ISSN 2192-1806

29. Dumas J-B (1831) Procedes de l'analyse organique. Ann Chim Phys 247:198-213

30. Hill DT, Cobb SA, Bolte JP (1987) Using volatile fatty acid relation-ships to predict anaerobic digester failure. Trans ASAE 30(2):496-501

31. Clarke RTJ, Reid CSW (1974) Foamy bloat of cattle. A review J Dairy Sci 57:753-785

32. Moeller L, Lehnig M, Schenk J, Zehnsdorf A (2014) Foam formation in biogas plants caused by anaerobic digestion of sugar beet, Bioresource Technol (accepted)

33. Ganidi N, Tyrrel S, Cartmell E (2011) The effect of organic loading rate on foam initiation during mesophilic anaerobic digestion of municipal wastewater sludge. Bioresource Technol 102:6637-6643

34. Carroll JJ, Slupsky JD, Mather AE (1991) The solubility of carbon dioxide in water at low pressure. J Phis Chem Ref Data 20(6):1201-1209

35. Kougias PG, Boe K, Angelidaki I (2013) Effect of organic loading rate and feedstock composition on foaming in manure-based biogas reactors. Bioresource Technol 144:1-7

36. Cabirol N, Barragán EJ, Durán A, Noyola A (2003) Effect of aluminum and sulphate on anaerobic digestion of sludge from wastewater enhanced primary treatment. Water Sci Technol 48(6):235-240

37. Scholwin F, Liebetrau J, Edelmann W (2009) Biogaserzeugung und -nutzung. In: Kaltschmitt M, Hartmann H, Hofbauer $\mathrm{H}$ (eds) Energie aus Biomasse, 2nd edn. Springer, Verlag Berlin Heidelberg, pp 851-990 
38. Moeller L, Krieg F, Zehnsdorf A (2013) Effect of coarse grain on foam formation in biogas plants. Agricultural Engineering (Landtechnik) 68(5):344-348

39. Junker B (2007) Foam and its mitigation in fermentation systems. Biotechnol Prog 23:767-784

40. Kroiss H (1986) Anaerobe Abwasserreinigung, Wiener Mitteilungen, Wasser-Abwasser-Gewässer, Bd 62. In [27].

Submit your manuscript to a SpringerOpen ${ }^{\circ}$ journal and benefit from:

- Convenient online submission

- Rigorous peer review

- Immediate publication on acceptance

- Open access: articles freely available online

- High visibility within the field

- Retaining the copyright to your article

Submit your next manuscript at springeropen.com 